NBER WORKING PAPER SERIES

\title{
CUT TO THE BONE? HOSPITAL TAKEOVERS AND NURSE EMPLOYMENT CONTRACTS
}

\author{
Janet Currie \\ Mehdi Farsi \\ W. Bentley MacLeod \\ Working Paper 9428 \\ http://www.nber.org/papers/w9428 \\ NATIONAL BUREAU OF ECONOMIC RESEARCH \\ 1050 Massachusetts Avenue \\ Cambridge, MA 02138 \\ December 2002
}

This paper was prepared for a Festschrift in honor of Orley Ashenfelter. The authors thank Phillip Levine, and participants at the Festschrift conference in October 2002 for helpful comments. Ilya Berger provided research assistance, and we thank the Center for Law, Economics and Organization for research support. We are solely responsible for any errors. The views expressed herein are those of the authors and not necessarily those of the National Bureau of Economic Research.

(C) 2002 by Janet Currie, Mehdi Farsi, and W. Bentley MacLeod. All rights reserved. Short sections of text not to exceed two paragraphs, may be quoted without explicit permission provided that full credit including, (C) notice, is given to the source. 
Cut to the Bone? Hospital Takeovers and Nurse Employment Contracts

Janet Currie, Mehdi Farsi, and W. Bentley MacLeod

NBER Working Paper No. 9428

December 2002

JEL No. I11

\title{
$\underline{\text { ABSTRACT }}$
}

This paper uses data from the 1990s to examine changes in the wages, employment, and effort of nurses in California hospitals following takeovers by large chains. The market for nurses has been described as a classic monopsony, so that one might expect increases in firm market power to be associated with declines in wages. However, we show that if one extends the monopsony model to consider effort, or if we apply a basic contracting model to the data, then we would expect to see effects on effort rather than on wages. This prediction is bourne out by the data - nurses see few declines in wages following takeovers, but see increases in the number of patients per nurse, our measure of effort. We also find that these changes are similar in the largest for-profit and non-profit chains, suggesting that market forces are more important than institutional form.

\author{
Janet Currie \\ UCLA \\ Department of Economics \\ University of California, Los Angeles \\ 90095-1477 \\ and NBER \\ currie@simba.sscnet.ucla.edu \\ W. Bentley MacLeod \\ Department of Economics and The Law School \\ University of Southern California \\ Los Angeles, CA 90089-0253 \\ bentley@law.usc.edu
}

Mehdi Farsi

Department of Economics

University of Lugano

and Center for Energy Policy and Economics

Federal Institute of Technology

ETH Zentrum, WEC C20 8092

Zürich, Switzerland 


\section{Introduction}

In a seminal paper, Ashenfelter and Hannan (1986) examine the effects of product market concentration on the wages and employment of women in the banking industry. This paper examines the labor market effects of consolidation in the hospital industry in California over the 1990s. This industry has experienced remarkable changes in market structure in a very short period of time. Over half of all hospitals in California are now part of a multi-hospital chain, and the six largest chains control over a third of the hospitals (Spetz et al. 1999, 2000). This type of consolidation is apparent all over the country, and California is on its leading edge. Although a good deal of qualitative evidence exists regarding the effects of these mergers, no quantitative research on the impact of these takeovers on employment contracts has been conducted.

The hospital sector is large, accounting for $3 \%$ of GDP, and individual hospitals are often important employers in the markets that they serve. These facts have generated a literature on monopsony in the market for nurses. The standard monopsony model predicts that employment will be reduced below the competitive level, with subsequent reductions in wages. Researchers such as Yett (1975) view hospitals as "classic" examples of monopsonists, pointing to chronic shortages of nurses as evidence of hospital market power. However, careful empirical work by Sullivan (1989) and Hirsch and Schumacher (1995) find little evidence that market power reduces wages. Boal and Ransom (1997) conclude in their review of the monopsony literature that if monopsony in the market for nurses exists, then the extent of monopsony power is small.

These negative findings are puzzling in light of the hostility that California nurses have shown towards hospital takeovers and large chains. However, surveys of nurses indicate that they associate takeovers primarily with increases in workload rather than with reductions in wages. We extend the standard monopsony model by considering an employer who sets minimum effort levels as well as wages and employment. We show that in this model, increases in market power are associated with increases in effort but have ambiguous effects on the wage. We find that this model is consistent with the data in that the most striking effect of takeovers is that they increase effort, measured as the number of patients each employee is responsible for per day. This effect is most noticeable in the two largest chains: Catholic Healthcare West and Tenet which is notable in view of the fact that the former is a non-profit chain while the latter is a for-profit chain. Thus, our results lend support to another claim by nurses that non-profit chains are "... really no different in their business 
philosophy [than for-profit firms], in the way they provide care or the way they treat workers" (Sal Rosselli, President of Local 250 of the Service Employees International Union, quoted in Hall, 1996).

We show that the results regarding wages, employment, and effort can also be generated in a contracting model if wages are "contractible" while effort is not. Under certain assumptions the two models can be distinguished by examining effects on revenues: Monopsony predicts declining revenues (but increasing profits) with takeovers while contracting predicts increasing revenues.

The rest of the paper proceeds as follows: Section 1 provides some background on hospital mergers and hospital chains in California. Section 2 describes the data, and section 3 lays out models which include effort as well as work hours and wages. Our main results are in section 4 , while section 5 concludes.

\section{Background}

\subsection{Why do Hospitals Merge?}

Several reasons have been given for hospital mergers, and for hospital consolidation more generally (see Barro and Cutler, 1997 and Sloan, 2002 for summaries of this literature). First, case studies suggest that hospitals that merge typically experience financial difficulties in the years leading up to the merger. Technological improvements in health care have led to shorter stays for many classes of patients (such as women giving birth), leading to a general shakeout of excess capacity in the hospital industry.

Second, the rise of managed care organizations such as Health Maintenance Organizations (HMOs) has transformed the health care market (c.f. Currie and Fahr, 2002a,b). Hospitals may band together in order to deal with the financial pressures created by these organizations. Or more generally, they may join together to increase market power in the product market in order to raise prices, or in the labor market in order to reduce costs. Buerhaus and Staiger (1999) show that after growing through the 1980s, the wages of nurses began to fall in the 1990s, and that declines started sooner in states with high HMO enrollments than in states with low enrollments. These considerations suggest that it will be important to control for differences between hospitals and between hospital markets, when examining the effects of mergers.

A third possibility is that successful chains bring a more efficient mode of production to 
target hospitals. Conversations with executives of Columbia/HCA suggest that they impose a centralized set of procedures on all their hospitals and also track key indicators for each hospital centrally. ${ }^{1}$ Such measures might increase the efficiency of production. Cutler and Horowitz (2000) offer case study evidence which suggests that for-profit hospital chains are better able to gain public-sector reimbursements, which again suggests that they may be better managed than other hospitals.

A closely related idea is that badly managed hospitals are more likely to be takeover targets. If hospital management would have improved even in the absence of the takeover, then we may wrongly attribute regression to the mean to the merger. Ashenfelter (1978) observes that people often enter training programs when they have temporary dips in earnings. The "Ashenfelter dip" makes data on post-training earnings increases difficult to interpret, because we would have expected earnings to increase from their temporarily low levels with or without the training. The main issue in the merger context then, is whether one would have expected management to improve in the absence of an intervention such as a takeover. One way around this difficulty is to see whether all takeovers have similar effects, as we would expect to see if takeovers routinely occurred when management was at its worst.

\subsection{Evidence Regarding Effects of Hospital Mergers}

Several previous studies have examined the effects of mergers on hospital financial performance, and patient care, with mixed results. ${ }^{2}$ Barro (2000) examines the financial performance of Massachusetts hospitals over the period 1985 to 1995. He finds that although mergers were associated with reductions in beds and staff, there is little evidence that mergers reduced costs normalized using hospital assets. Conner et al. (1998) study 3500 general hospitals from 1986 to 1994 and find some evidence of reduced costs per discharge after hospital mergers. Dranove (1998) suggests that scale economies exist only for small hospitals, and that there are no scale efficiencies possible for hospitals with 200 or more beds. Summarizing the mixed evidence on scale economies, Dranove (2000) concludes that cost savings from mergers are not substantial. Since labor costs are the largest component of hospital costs, these results have implications for whether employment contracts are likely

\footnotetext{
${ }^{1}$ The first author met with executives of Columbia/HCA as part of the April 2000 NBER Conference on the Industrial Organization of Medical Care.

${ }^{2} \mathrm{~A}$ related literature examines the effect of conversions from non-profit (NP) to for-profit (FP) status and vice-versa. This is not the same question since the majority of hospitals acquired by FP chains are FP and vice-versa. According to Spetz et al. (1999), only $20 \%$ of changes in ownership involved a change in the NP or FP status of the hospital.
} 
to be affected.

However, Gaynor and Vogt (2000) argue that the empirical research on scale economies is plagued with difficulties. First, the caseload mix varies across hospitals. Large hospitals tend to treat more severely ill patients, and thus have higher costs. Moreover, these hospitals deliver a broader range of services. Thus, scale economies might be realized by consolidating the services of several hospitals, as a chain could do.

Several studies have suggested that hospital markets are not perfectly competitive and that mergers can result in higher prices. For example, Keeler et al. (1999), conclude that mergers can drive up prices by as much as 26 percent. Simpson and Shin (1998) show that the prices of non-profit hospitals are higher in more concentrated markets. Krishnan (2001) examines prices within Diagnosis Related Groups (DRGs) and finds that prices rise when merging hospitals gain significant DRG-specific market share. On the other hand, Barro (2000) found no evidence of increases in market power, and Dranove and Satterthwaite (2000) argue that heterogeneity in provider services makes it difficult to reach firm conclusions about the relationship between market concentration and prices. Moreover, it is difficult to define a market, and data on actual prices paid for services are often unavailable.

Increases in product market power could be reflected in lower quality services rather than higher prices. Hamilton and Ho (2000) find that hospital mergers have no effect on the mortality of heart-attack patients, but that the acquisition of independent hospitals raises readmission rates. Madison (2001) also examines heart-attack patients, and finds that patients treated in a multi-hospital system receive more intensive treatments at lower expenditure, but that there is no change in mortality. Farsi (2002) reports similar results for elderly heart-attack patients in California, while Kessler and McClellan (1999) find that the mortality of heart-attack patients is higher in more concentrated markets.

\subsection{Effects on Labor Markets}

In contrast to the relatively well-developed literature on the effects of mergers on prices and patient outcomes, there has been little attention to the effects on labor markets, at least by economists. This is surprising, since the quantity and quality of nursing care is likely to be highly related to outcomes (Needleman et al., 2002). Moreover, a good deal of qualitative evidence on the effects of takeovers on workers exists. Corey-Lisle et al. (1999) and Sochalski and Aiken (1999) note that reductions in the registered nursing (RN) staff following takeovers require nurses to care for more patients who are sicker on average, and 
also to spend more of their time supervising unlicensed aides rather than engaging directly in patient care. Moreover, nurses are more likely to be rotated through different areas of the hospital in order to respond to fluctuations in demand, rather than to have "downtime" when their own unit is less busy. Davidson et al. (1997) finds that these changes have increased voluntary turnover among nurses. Clark et al. (2001) report on responses to a survey of 1,500 nurses. They find that nurses who experienced job restructuring related to mergers had more negative views of the climate for patient care than other nurses.

These staffing issues have become major themes in the drive to organize California nurses and hospital workers. Historically, only workers in public hospitals were unionized. ${ }^{3}$ However, in the last few years, the two unions representing nurses and hospital workers, the Service Employee's International Union (SEIU) and the California Nurses Association (CNA), have made great strides, organizing many hospitals in 2001 and 2002. Moreover, nurses have been lobbying the California Department of Health Services (DHS) to pass a law mandating minimum nurse-patient ratios. The DHS issued proposed minimum staffing ratios in January of this year, which may become law.

This brief review of the literature suggests first, that the issue of how mergers affect costs (which are dominated by labor) is unresolved; second, that it is important to control for heterogeneity between hospitals and health care markets when examining the effects of mergers; and third, that it will be important to consider "effort" as well as wages and employment when examining the effect of mergers on hospital labor markets.

\subsection{California's Hospital Market ${ }^{4}$}

As discussed above, six chains own more than a third of hospitals in California. In this paper, we will examine the impact of joining each of five large chains: Catholic Healthcare West, Sutter, Columbia-HCA, Tenet, and OrNda. We define a large chain, somewhat arbitrarily, as a chain that owned at least 10 hospitals for 3 or more years in our sample. Many of the hospitals in our data set merged with one or two other hospitals over our sample period to form groups of two or three hospitals. We do not treat these as "chains".

Tenet and Columbia/HCA are the largest for-profit hospital corporations operating in California, with 40 and 10 general acute care hospitals each in 2002, respectively. Tenet was

\footnotetext{
${ }^{3}$ The major exception to this generalization was Kaiser, whose workers were unionized over our sample period. Kaiser's 27 hospitals are not included in our main sample, because Kaiser does not report all of the information on wages and employment.

${ }^{4}$ Much of the material in this section is drawn from Spetz $(1999,2001)$.
} 
formed by the merger of American Medical Holdings and National Medical Enterprises in 1995. In 1997, it absorbed 17 hospitals from the OrNda chain, which itself had been formed via the merger of American Healthcare Management and Summit Health Ltd. in 1994. We treat NME hospitals as Tenet in our models. Columbia/HCA has grown via a series of smaller acquisitions.

The non-profit chains we focus on are Catholic Healthcare West (CHW) and Sutter Health. Sutter is a secular non-profit hospital group which currently owns 26 acute care hospitals in northern California. CHW represents the merger of several small groups of hospitals owned by different, mainly Catholic, religious orders. CHW now operates 42 general acute care hospitals in California, making it the largest non-profit hospital group in the state. However, as Spetz et al. (1999) argue convincingly, the concept of "ownership" is somewhat murky for Catholic non-profits. They quote an official at CHW who explained that under cannon law, each hospital is owned by its religious order. Thus, it is not clear a priori how much direct control is exercised by the larger organization, although it is unlikely that a hospital could unilaterally choose to leave CHW.

We omit Kaiser Permanente which owns 27 hospitals in California from our data since Kaiser does not report much of the data we use. We do however take account of their holdings when constructing measures of hospital firm's market share below. Also, while we include their hospitals in the data, we do not treat Adventist Health as a chain. This group, which is affiliated with the Seventh Day Adventist Church, owns 15 hospitals but did not experience changes in ownership over our sample period. Kaiser also experienced few ownership changes.

\section{Data}

The data for our study come from California's Hospital Disclosure Data (CADD) for fiscal years 1989/90 to 1998/99. The CADD consists of information from hospital financial reports (disclosure reports) which are submitted annually to the State of California's Office of Statewide Health Planning and Development (OSHPD). All non-federal hospitals are required to report (although as discussed above, Kaiser does not submit full reports). Hospitals include information about ownership, for-profit or non-profit status, number of beds, costs and revenues, and personnel.

The reports include the number of productive hours (hours actually worked), non-productive hours (paid time off including vacation, sick-leave, and holidays), and hourly wages for 
seven categories of personnel: Registered Nurses (RNs), Licensed Vocational Nurses (LVNs), aides and orderlies, management and supervisory, technical and specialist, clerical and other administrative, and workers in food and accommodation services ("environmental"). ${ }^{5}$ An eighth category includes all other classifications including salaried physicians and nonphysician medical practitioners. Under California law, only public hospitals can employ physicians. Hence, the number of physicians who are treated as employees is small. In this study we focus on nursing staff (RNs, LVNs, and aides), since the other categories of workers are more heterogeneous, making it difficult to interpret changes in group wages. ${ }^{6}$

As Spetz et al. $(1999,2001)$ report, the OSHPD data are quite noisy. Some of the most important problems include: Non-standard reporting periods, multiple reports in a single year, and late reporting or failure to report ownership changes. This latter problem is particularly acute for non-profit chains, probably because of the ambiguity about ownership noted above. Since the beginning and end dates of each reporting period are included in the data, it is relatively easy to adjust for the first two problems. ${ }^{7}$ Spetz et al. (1999) includes a data appendix with corrected ownership data, which we have used to correct the OSHPD data. $^{8}$ We also discovered many cases in which psychiatric hospitals or drug rehabilitation centers (such as the Betty Ford clinic) were incorrectly coded as general purpose acute care hospitals, and we deleted these from our data set. We do not have systematic data on union status, though as discussed above, most unionization activity has occurred very recently and not during the period covered by our data. ${ }^{9}$

\footnotetext{
${ }^{5}$ Nurses working as supervisors or instructors are included in the management/supervision and techni$\mathrm{cal} / \mathrm{specialist}$ categories.

${ }^{6}$ For example, technical employees include accountants as well as x-ray technicians.

${ }^{7}$ In our analyses, the unit of observation is a hospital-year. In order to create a single observation for each hospital-year we first arranged the data so that every report was considered in the fiscal year (beginning June 30) that covered the largest part of the reporting period. We then combined multiple reports for a single year to form a single record. For example, we took weighted averages (where the weights were the number of days in each reporting period) of stock variables such as assets and personnel, and we took weighted sums of flow variables such as discharges, costs, and revenues. If the hospital's ownership changed, we used the report that covered the largest part of the year.

${ }^{8}$ The appendix covers data through 1996. They do however, report on mergers that took place between 1996 and 1999 in the text, and we verified ownership of hospitals in recent years using parent organization web sites and hospital web sites.

${ }^{9}$ Given that unionization drives are currently being conducted at many hospitals, and are vigorously resisted by management, the SEIS and CNA are reluctant to share information about their organizing activities. Thus, we were unable to obtain a complete list of unionized hospitals with dates of unionization. However, the SEIS negotiated a breakthrough agreement with CHW in 2001, covering 20 hospitals in 15 cities. The CNA also organized 8 large hospitals in 2001, accounting for approximately 2,000 nurses. News reports indicate that these victories were regarded as important turning points in the battle to unionize California hospital workers.
} 
Figure 1a shows the distribution of hospitals across California in 1990, while figure 1b shows California's "health service areas". HSAs are health care markets, as defined by the state. They reflect the fact that hospitals are more densely concentrated in urban areas (so that urban HSAs cover smaller areas). Figures $2 \mathrm{a}$ and $2 \mathrm{~b}$ show the growth in the chains we study between 1990 and 1999, and their geographical coverage. The figures illustrate the rapid growth of chains, and their concentration in urban markets. The for-profit chains tend to be slightly more concentrated in urban areas than the non-profit chains. There is also some division between northern and southern California: for example, Sutter operates only in the north, while Tenet has moved into the Los Angeles area very aggressively.

Increased concentration has also occurred because of hospital closures. A recent report commissioned by the California Attorney General examined 17 hospital closures that occurred between 1995 and 2000 (Nicholas C. Petris Center, 2001). Tenet was involved in at least five of these closures, including four closures of facilities that it acquired when it absorbed OrNda. CHW closed one hospital in 1999. The report indicated that the closed hospitals were generally small (all of the closures considered in the report, including some that occurred in 2000, accounted for three percent of California's hospital beds) and in considerable financial difficulty. Some hospitals closed because they were unable to meet more stringent seismic requirements, and many more hospitals are expected to close for this reason in future. Many shuttered hospitals remained medical centers, converting to long-term care or outpatient facilities. In this paper, we consider employment contracts at all operating acute-care hospitals. We do however, account for the effect of closures indirectly when we consider the effect of the firm's share (of the beds in the local hospital market) on outcomes. We also account for changes in the number of beds in the market over time by including $\mathrm{HSA}^{*}$ year effects in our regression models, as discussed further below.

Increased concentration in the hospital market is shown in Figure 3, which plots Herfindahl indices for four health service areas. The Herfindahls are computed using the number of acute care beds in each hospital. Figure 3 illustrates that while concentration has increased throughout the state, it has grown much more rapidly in northern than in southern California. Sacramento was the most concentrated market over much of the period, with San Francisco catching up in the last two years of the sample. In contrast, the degree of concentration is much smaller in Los Angeles and San Diego, although it has been rising.

Means of key variables are shown in Table 1 for all hospitals and separately for each chain. The unit of observation is a hospital year, and a hospital is included in the column for the chain only in the years when it actually belonged to that chain. The first three measures 
in Table 1 show the "output" of the hospital. One can see that there is little systematic difference between the chain hospitals and other hospitals in terms of number of beds, the number of patient days (per day), or gross patient revenues per day. Gross patient revenues are what is actually billed rather than what is collected, and so reflect the value of services rendered. While CHW hospitals are larger than the others with an average of 235 beds, Sutter and Tenet both have hospitals that are somewhat smaller on average than the overall mean of 183 beds.

The next four rows show wages for four categories of nursing personnel: registered nurses (RNs), Licensed Vocational Nurses (LVNs), aides, and contracted nursing personnel in real 2001 dollars. RNs are more highly trained then LVNs, who in turn are more skilled than aides. Beginning in December 1992, OSHPD also asked hospitals about the employment of contracted nursing personnel. Unfortunately, data for RNs, LVNs, and aides working under contract are all grouped together, although the high average wages for this group suggest that they are relatively skilled workers. These data do not suggest monopsony, since if anything nurses working for large chains are more highly paid than other nurses. Note that this does not reflect a hospital size effect, since, as we saw above, hospitals are not systematically larger in large chains. However, it might reflect a firm size effect, something we will control for below. It is also possible that the higher wages in chains reflect the concentration of chains in large urban areas.

We next show the number of nursing hours employed by the hospital (per day). It is evident that the average hospital employs more RNs than LVNs or aides. Data on contract worker hours (which may be zero) are reported for only 63 percent of the hospital-years in our data, but where it is reported, the number of contract worker hours is very small relative to RN hours. While less skilled LVN and aide hours may be substituted for RN hours, the literature suggests that RNs remain ultimately responsible for supervising less skilled workers. Hence, in our empirical work below we focus on RN hours, and on total nursing hours measured as the sum of RN, LVN, and aide hours. We also show results for an alternative measure which includes the contract nursing personnel, although it is available only from 1993 on, and is generally quite similar to the RN plus LVN plus aide total.

Table 1 also shows several measures of nurse "effort". These measures attempt to capture the number of patients a nurse would be responsible for during his or her shift. This focus on patients per nurse corresponds to the emphasis on staffing ratios by nurse organizations. Since hospitalized patients require 24 hour nursing care, we take patient days (per day), divide by total productive hours (per day), and multiply by 24 . The first measure, "RN 
effort" is the number of patients each registered nurse attends. The average is 4.36 in nonchain hospitals, compared to 3.69 at CHW and 3.37 at Tenet.

However, when we consider all available nursing hours, or "total effort", hospitals appear to be much more similar. For example, the non-chain hospitals have a mean of 2.23 patients per nursing staff member compared to 2.31 and 2.28 for CHW and Tenet respectively. Thus, more of the care is provided by RNs in chain hospitals. Again, these differences could reflect either the types of services offered by the hospitals (e.g. hospitals treating sicker patients would require more skilled staff), or differences in the markets served by chain and non-chain hospitals. It will be important to control for these differences below.

Finally, Table 1 indicates the average firm share of each hospital. On average, hospitals belong to firms which have only 3 percent of the local acute care hospital beds. But in the largest chains, hospitals belong to firms which have closer to 10 percent of the available beds on average. The hospital whose firm has the largest share is San Francisco General Hospital Medical Center, which has 33 percent of it's HSA's beds, and does not belong to a chain. Among the chains, the maximum firm share enjoyed in any market is 28 percent for CHW in the Santa Barbara area; 26 percent for Sutter in the Sacramento area; and 21 percent for Tenet in Orange County.

\section{The Model}

The question we wish to address is how revenue, wages, employment, and effort change when a hospital is taken over. There are two sources of change that are considered here. The first is that the acquiring firm increases the hospital's revenue stream. Marginal revenue may go up with a takeover because the firm is better able to negotiate with HMOs or otherwise able to charge higher prices for its services, because the firm is more effective in generating revenues from government (as in Cutler and Horowitz), or because it improves the collection of outstanding bills. Secondly, a take over could result in a reorganization of production. In this section, the implications of these two sources of change are considered in the context of three simple models of employment: perfect competition, monopsony and contracting.

The standard monopsony model is based on the idea that a large local employer can affect wages via its demand for labor. This implies that demand is reduced below the competitive level, to reduce wages. However, the standard monopsony model supposes that wages depend only upon the supply and demand for nurses. In practice, a job at a particular hospital is likely to have features that make it more or less desirable than other similar positions, and 
hence as Rosen (1975) has argued, market wages should reflect not only current labor market conditions, but also the nature of working conditions. Although it is difficult to find evidence of such compensating wage differentials in practice, the theory is very clear and some evidence does exist. For example, Abowd and Ashenfelter (1981) have shown that the probability of a layoff can affect the wage premium offered by a firm. In this paper, we focus upon the consequence of incorporating "work intensity" or "effort" on the compensating differential offered by the firm.

Let $q$ denote the effort per hour of a nurse. The total output from $H$ hours of nursing services is $q H$. The utility per hour of a nurse is assumed to be decreasing in the level of effort, and given by:

$$
U(w, q)=w-V(q),
$$

where $w$ is the hourly wage, and $V(q)$, is the disutility of effort. The function $V$ satisfies $V(0)=0, V^{\prime}, V^{\prime \prime}>0$, with $\lim _{q \rightarrow \bar{q}} V(q)=\infty$, where $\bar{q}$ is the maximum effort possible in the market. We cannot observe individual nurses, and hence it is assumed that they all have the same preferences within a single category of employee. Let $q^{0}$ be the customary level of effort in the market, and $w^{0}$ the corresponding market wage.

Let $\alpha R(q H, K)$ be the revenue function for a hospital, where $\alpha$ is a revenue shifter, $q H$ is total nurse services, and $K$ is capital. In the short run capital is assumed to be fixed, and hence the question is how a takeover affects wages, effort, and hours?

\subsection{The Competitive Model}

First suppose that the labor market remains competitive after a takeover, in which case the only way for the takeover to have an effect is through the revenue shifter, $\alpha$. The problem solved by the owners of the hospital is:

$$
\begin{gathered}
\max _{q, H, w} \alpha R(q H, K)-H w \\
\text { subject to: } \\
U(w, q) \geq U\left(w^{0}, q^{0}\right) .
\end{gathered}
$$

It is assumed that the revenue function is strictly concave and increasing in its arguments. The owner can increase effort $q$ above the market norm $q^{0}$, by paying a compensating differential $D(q)=V(q)-V\left(q^{0}\right)$, and hence the nurse's wage is $w=w^{0}+D(q)$, and the firm's 
profit function can be written:

$$
\Pi\left(H, q, w^{0}\right)=\alpha R(q H, K)-H\left(w^{0}+D(q)\right),
$$

and hence the first order conditions for an optimum are given by:

$$
\begin{aligned}
\partial \Pi / \partial H & =\alpha R^{\prime}(q H, K) q-\left(w^{0}+D(q)\right)=0, \\
\partial \Pi / \partial q & =\alpha R^{\prime}(q H, K)-D^{\prime}(q)=0 .
\end{aligned}
$$

Notice that substituting the first order condition (4) into condition (3) results in the condition:

$$
q D^{\prime}(q)-D(q)=w^{0} .
$$

This implies that the level of effort is independent of the revenue shifter. The first order condition (4), combined with the concavity of the revenue function implies that $q H$ is increasing with $\alpha$, which combined with the previous result implies that hours demanded, $H$, is increasing with $\alpha$. These results are summarized in the following proposition:

Proposition 1 If the hospital's marginal revenue increases in a competitive labor market, then demand for labor $(H)$ and revenue increases. If the firm cannot affect the market wage, then effort and wages paid remain unchanged when the firm's marginal productivity increases.

This result implies that when a firm takes over a hospital, a reorganization of the hospital leading to an increase in marginal productivity should not result in an increase in the effort exerted by nurses, nor in an increase in wages if the hospital is sufficiently small that it cannot effect the local market wage for nurses.

\subsection{Monopsony}

Now consider the case in which the firm's hiring decisions can affect the local labor market. Market power is modelled by supposing that the local wage, $w^{0}(H)$, is an increasing function of total hours demanded in the local market. Suppose a single hospital employs $H^{i}$ hours and it is a member of a firm which employs $H^{0}$ hours at its other hospitals, while the other firms employ a total of $H^{r}$ hours. In that case the total hours in the labor market are $H=H^{i}+H^{0}+H^{r}$.

The hospital chooses its hours taking into account the effect that its employment decisions

have upon the wage costs of the chain owning the firm. Let $\varepsilon_{s}=\frac{H}{w^{0}} \partial w^{0}(H) / \partial H$ be the 
wage elasticity of labor supply, and $S=\frac{H^{i}+H^{0}}{H}$ be the share of the market owned by the firm, then the first order condition for hours $H^{i}$ is given by:

$$
0=\partial \Pi^{i} / \partial H+\partial \Pi^{i} / \partial w^{0} \cdot \partial w^{0} / \partial H=\alpha R^{\prime}\left(q H^{i}, K\right) q-D(q)-w^{0}(H)\left(1+\varepsilon_{s} S\right)
$$

This can be written in the more familar form:

$$
\text { Marginal Revenue }=\text { Marginal Cost }+w^{0}(H) \varepsilon_{s} S
$$

which implies that the monoponistic firm restricts hours relative to the competitive case.

Let $q^{*}(H, \alpha)$ be the solution to the first order conditions for effort given by:

$$
\alpha R^{\prime}\left(q H^{i}, K\right)-D^{\prime}(q)=0
$$

From the concavity of the revenue function it follows that $\partial q^{*} / \partial \alpha>0$ and $\partial q^{*} / \partial H<0$. Substituting this first order condition into the condition for hours one has:

$$
M\left(q^{*}(H, \alpha)\right)=w^{0}(H)\left(1+\varepsilon_{s} S\right),
$$

where $M(q)=q D^{\prime}(q)-D(q)$ is an increasing function of $q$. From this expression one can determine the hours choosen as a function of the concentration in the market. In particular, it implies that $\partial H / \partial S<0$, and therefore $\partial q^{*} / \partial S>0$. This increase in effort implies via equation (7) that revenue decreases at the hospital when concentration increases.

The wage paid to an individual is given by the market wage plus the compensating differential, or

$$
w^{*}(H)=w^{0}(H)+D\left(q^{*}(H, \alpha)\right) .
$$

Since $q^{*}(H, \alpha)$ is decreasing in $H$, a decrease in $H$ results in an increase in the compensating differential $D\left(q^{*}(H, \alpha)\right)$, and a decrease in the market wage $w^{0}(H)$, hence the effect on wages paid to employees is ambiguous. This is illustrated in Figure 4. Notice that the change in the wages paid to the employee, $w^{c}-w^{q}$, is smaller than the change that would occur in the standard monopsony model without effort, which would be given by $w^{c}-w^{m}$.

Equation (8) can also be used to determine the effect of a change in the revenue shifter. Differentiating with respect to $\alpha$ one sees that $d H / d \alpha>0$ and $d q^{*}(H(\alpha), \alpha) / d \alpha>0$, and therefore wages, as well as revenues, rise. These effects are summarized in the following proposition. 
Proposition 2 In a monopsonistic market, an increase in a firm's market share results in increased effort, and a decrease in hours and revenue. The effect on wages paid is indeterminate. Keeping market share fixed, an increase in the ability to generate revenue $(\alpha)$ results in more effort, more hours, more revenue and a higher wage.

Thus in the case of monopsony, the addition of effort modifies the standard results in two significant ways. First it implies that the effect of market power on wages paid is ambiguous because an increase in market power results in lower demand for labor (which depresses wages) and higher effort (which increases wages). The model would be rejected if we observed a decrease in effort and an increase in wages. Secondly, the first order condition for effort implies that the revenue shifter $\alpha$ effects wages and hours through its effects on effort. In other words, when $\alpha$ goes up, then effort should rise, as should revenue and hours.

\subsection{Contracts}

The monopsony model supposes that firms exercise market power through their labor demand decisions. However, beginning with Simon (1951), there is a large literature that views the employment relationship as the outcome of a contract between the employee and the employer. Beginning with Williamson, Whacter and Harris (1975), the literature highlights the fact that even if the labor market is competitive, a contract is needed to protect relationship specific rents that arise after an employee has accepted a position.

Firms may invest in training the worker for hospital specific tasks. Among workers, examples of relationship specific investments include finding accommodation that is closer to ones place of work, learning about job specific characteristics or routines, and learning to cooperate with co-workers. Grout (1984) and Hart and Moore (1998) have shown that in the absence of a contract, both the firm and employee will underinvest, a problem that can be solved by having a wage that is fixed in advance. Macleod and Malcomson (1993) have shown more generally, that under the appropriate conditions the optimal contract entails a fixed wage that is periodically renegotiated to reflect market conditions. Ashenfelter and Brown (1986) use data on a sample of unionized workers to study the properties of these types of employment contracts.

A difficulty with using contract theory to study the market for nurses in California is that they are employed "at-will", and therefore when a merger occurs there is no legal obligation for the new owner to respect any previous wage agreements. Moreover, given that it is costly for incumbent workers to leave and find alternative employment, the new firm 
can unilaterally decrease wages to the point that current employees are indifferent between staying and leaving. In this case the allocation would be the same as for the competitive labor market described above, and the takeover would not entail any change in effort.

However, given that it is efficient for the firm to enter into long term employment contracts, then firms must also be able to enter into implicit agreements that employees feel they can rely on. Wages and effort demanded are quite different in this regard. The wage is a fixed amount that is paid regularly, and the amount is easily verifiable. Thus, if the new owner were to unilaterally lower wages, then this would signal to employees that they should not make any relationship specific investments, and the resulting outcome would be inefficient. ${ }^{10}$

But this reasoning is unlikely to apply to "effort". As Simon (1951) emphasizes, an important feature of the employment relationship is the right of the employer to exert "authority" over an employee. In the hospital context the amount of work that an employee is expected to perform depends on the current demand for services. This demand can vary hourly in the face of unexpected events such as car accidents, patients with complications, and so on.

Hence, when an employee is hired, effort would typically not be explicitly specified. Rather the individual would be given a description of the job from which expected effort could be inferred. This arrangement implies that as long as the employee's utility remains greater than in her next best alternative employment, the firm can vary demand for effort without it being immediately obvious that they are violating their implicit agreement, especially since, in the context of a takeover, it is reasonable for the firm to engage in a reorganization of work.

These arguments suggest that in the event of a takeover the firm may be reluctant to lower wages, but will feel free to adjust effort, subject to a market constraint. If the new owner reduces employment, then incumbent workers faces the possibility of losing their relationship specific rent, which is denoted by $K_{w}>0$. In other words the employee will not choose to leave as long as her utility loss from the merger is less than $K_{w}$. Thus the optimization

\footnotetext{
${ }^{10}$ In particular, see MacLeod and Malcomson (1998) for a discussion on how norms of fairness may arise as an equilibrium phenomena in markets to solve this commitment problem.
} 
problem faced by the new owner would be given by:

$$
\begin{gathered}
\max _{q, H} \alpha R(q H)-H w^{0} \\
\text { subject to: } \\
U\left(w^{0}, q\right)+K_{w} \geq U^{0} .
\end{gathered}
$$

If the firm were to increase employment, then $K_{w}$ would be zero, and hence there is an asymmetry between increases and decreases in employment. Given a binding individual rationality constraint, the effort level that solves this problem is the solution to:

$$
D\left(q\left(K_{w}\right)\right)=w^{0}+K_{w}-U^{0} .
$$

The corresponding expression for hours is:

$$
\alpha R^{\prime}\left(q\left(K_{w}\right) H\right) q\left(K_{w}\right)=w^{0} .
$$

If the revenue function is concave then $H$ is decreasing in $K_{w}$ and increasing in $\alpha$.

This model has the following predictions. In the event of a takeover, effort increases, hours decrease, and wages are unchanged. There will also be an increase in revenue. If there are no relationship specific rents, then the contract model implies that an increase in $\alpha$ will result in more hours and higher revenues. With wages fixed, effort will also remain constant. These observations can be summarized as follows.

Proposition 3 If firms respect outstanding wage agreements and enforce pay equity among workers, then a takeover leads to fewer hours, more effort, and higher revenues. If the takeover is motivated solely by the opportunity to shift the revenue function outwards (i.e. an increase in $\alpha$ ), then hours and revenues increase, and there is no effect on wages or effort.

\subsection{Summary}

In summary, if $\alpha$ is held constant, then the three models outlined above have the following predictions: 


\begin{tabular}{|c|c|c|c|}
\cline { 2 - 4 } \multicolumn{1}{c|}{} & Perfect Competition & Monopsony & Contract \\
\hline Revenue & 0 & - & + \\
\hline Wages & 0 & $?$ & 0 \\
\hline Hours & 0 & - & - \\
\hline Effort & 0 & + & + \\
\hline
\end{tabular}

Chart 1: Effect of an Increase in Firm's Market Share

If a merger is motivated only by the new management's ability to increase marginal revenues $(\alpha)$ then the three models have the following predictions.

\begin{tabular}{|c|c|c|c|}
\cline { 2 - 4 } \multicolumn{1}{c|}{} & Perfect Competition & Monopsony & Contract \\
\hline Revenue & + & + & + \\
\hline Wages & 0 & + & 0 \\
\hline Hours & + & + & + \\
\hline Effort & + & + & 0 \\
\hline
\end{tabular}

Chart 2: Effect of the Revenue Shifter, $\alpha$

\subsection{Empirical Model}

We estimate regression models using measures of output, revenue, wages, hours, and effort as the dependent variables. The first set of models examine the effects of belonging to a chain, where effects are allowed to differ between chains. They take the form:

$$
\begin{aligned}
\text { OUTCOME }_{i t}= & a_{i}+a_{1} C H W_{i t}+a_{2} S_{U T T E R} R_{i t}+a_{3} C O L U M B I A_{i t}+a_{4} T E N E T_{i t} \\
& +a_{5} O R N D_{i t}+a_{6} H_{S A} * Y E A R_{t}+u_{i t},
\end{aligned}
$$

where OUTCOME is one of the dependent variables discussed above, and CHW etc. are dummy variables equal to one if the hospital belongs to one of the specified chains. A vector of hospital-specific fixed effects, $a_{i}$, are included in order to control for factors such as the size of the hospital and the casemix at the beginning of the sample period. Finally, a complete set of HSA and year interactions control for market conditions in each HSA and year. These effects control for many omitted variables such as the behavior of local HMOs which might otherwise threaten the validity of our research design.

In models of the form (12), the estimated effects of joining one chain may be different from joining another either because there is variation in the size and market power of the chains, 
or because different chains adopt different production technologies. Moreover, although we include hospital fixed effects in the regression, the chain's share of capacity in the HSA can change even in the absence of a takeover. For example, the other hospitals in a chain will experience a change in firm share when the target firm joins. In order to try to differentiate between these effects, we also estimate a set of models that augment (12) by adding an explicit control for the firm's share of the local market, as measured by the fraction of HSA hospital beds that the firm controls.

The monopsony model predicts that an increase in firm share should reduce employment and increase effort, whether or not it is associated with a takeover (holding demand for services constant). The other models do not indicate any explicit role for firm share. However, in a contracting model firm share could reflect two offsetting effects. First, firms with larger market shares may have more ability to increase revenues per unit of output in the target firm (i.e. $\alpha$ ), which would lead to a positive correlation between firm share and hours in the absence of a direct measure of $\alpha$. Second, the amount of relationship specific capital $K_{w}$ could be increasing in firm share, in which case one might find a positive correlation between firm share, effort, and output, and a negative correlation between firm share and hours.

The effects of firm share are further explored by constraining variation in the effects of joining a chain to work primarily through differences in firm share. These models have the form:

$$
\begin{aligned}
\text { OUTCOME }_{i t}= & b_{i}+b_{1} A N Y C H A I N_{i t}+b_{2} A N Y C H A I N_{i t} * F_{S H A R E}, \\
& +b_{3} N O C H A I N_{i t} * F S H A R E_{i t}+b_{4} H_{S A} * Y E A R_{t}+v_{i t},
\end{aligned}
$$

where ANYCHAIN indicates that the hospital belongs to one of the five large chains, FSHARE is the share of the firm's beds in the local HSA, and NOCHAIN indicates that the firm does not belong to one of the five chains. In these regressions, we expect that $b_{2}$ will be positive if the effect of joining chains is larger when the chains have greater market share, while $b_{3}$ captures the effect of firm share in the other hospitals.

\section{Results}

Estimates of model (12) are shown in Table 2. The first section of the table deals with our measures of output, and indicates that takeovers by the five chains appear to have little consistent effect on the number of beds and generally positive effects on the number of 
patient days in the target hospital, though these are generally only significant at the ten percent level. Gross patient revenues increase, which may indicate either higher prices, or an increased intensity of services provided to patients (as would be the case with sicker patients, for example). Hence, it appears that output increases rather than decreases in the target hospital following takeover by a chain. This result is consistent either with a contracting model or with takeovers that are motivated by the opportunity to increase the marginal efficiency of revenue generation. But it is not consistent with a takeover whose primary goal is to increase the firm's power in the labor market.

Effects on wages are small and not consistently statistically significant. Takeovers by CHW are accompanied by reductions in the wages of RNs and aides of approximately 3 percent, though there are no changes in the wages of LVNs. At Columbia-HCA hospitals, there are slightly larger declines in wages of LVNs and aides, but no change in the wages of RNs. At Sutter, there are no changes in wages, and at Tenet, only the wages of contract workers fall. However, since we do not know the composition of contract workers, it is difficult to determine if this represents a shift towards less-skilled contract workers, or a true decline in wages. These findings are consistent with the previous literature on monopsony in the market for nurses, in that they do not provide evidence in support of the wage effects predicted by the traditional monopsony model.

The third section of Table 2 shows the effects of takeovers on hours. Here again, the effects are somewhat inconsistent. Only Tenet shows large and significant decreases in hours. CHW and Columbia-HCA also show some declines, though they are not statistically significant. Sutter is strikingly different, in that it shows a nine percent increase in total nursing hours. However, Sutter also showed the largest increases in output, suggesting that takeovers by Sutter may increase hospital revenues per unit of output $(\alpha)$.

The last section of Table 2 focuses on "effort", that is nurse hours normalized by patient days. These findings are much clearer. There is an increase in the effort required of both RNs and of the total nursing staff in the two largest chains, CHW and Tenet, as well as an increase in effort by the total nursing staff in OrNda. All but one of the estimated coefficients are positive, though those for the other chains are not statistically significant. The effect on effort is consistent with both our monopsony and contract models.

Table 3 provides estimates of a version of (12) which also includes the firm's share of capacity (i.e. beds) in the HSA. The first part of Table 3 suggests that the increase in firm share that accompanies takeovers is responsible for at least some of the increase in output at target firms since the coefficients on the "chain dummies" ( $a_{1}$ to $a_{5}$ ) fall or become 
statistically insignificant when firm share is controlled. Firm share has little effect on wages, except among contract workers, a result which is difficult to interpret given that we do not know the composition of the contract workers. Once again then, the estimates provide little support for the standard prediction that increased market power will be accompanied with decreases in wages.

Given the effects of firm share on output, it is perhaps unsurprising that firm share also has positive effects on total nursing hours. However, the increases in hours are smaller than the increases in patient days, so that increases in firm share increase nurse effort. Again, the effects of joining a chain are somewhat reduced, though still significant, when firm share is controlled, indicating that some of the effect of joining a chain operates through increases in market power as measured by firm share.

Table 4 shows estimates of (13). The results shown in Table 4 are consistent with the earlier tables in that they suggest that joining a chain is associated with increased output, as measured by patient days, as well as with increased nurse effort. There is no significant effect on wages or on hours. In contrast, firm share in non-chain hospitals has a positive effect on all four outcomes. It is particularly remarkable that RN wages rise with firm share, which is inconsistent with the simplest monopsony model. Firm share in chain hospitals has a positive effect on patient days and $\mathrm{RN}$ effort, but only the latter effect is statistically significant at the 10 percent level of confidence.

In summary, our empirical results are consistent with the previous literature, which found scant evidence of monopsony in the market for nurses, when focusing on wage and employment outcomes. There is little consistent evidence that increases in market power associated with joining chains reduce either wages or employment. On the other hand, they do increase the amount of effort required from the nursing staff, as measured by the number of patients each nurse and/or aide must attend to. This result is consistent with a broader view of the employment contract, in which the firm sets wages, employment, and also the minimum effort required of employees. It is also noteworthy that takeovers by different chains appear to have quite different effects. This result suggests that it is in fact the actions of the chains after the takeover which affect outcomes, rather than a matter of the chains being more likely to step in at a particular point in a deterministically unfolding sequence of events. 


\section{Discussion and Conclusions}

While in principle the introduction of effort into a monopsony model can explain why previous studies have not found much evidence of monopsony power on wages in this market, the case in favor of the monopsony model is still far from clear cut. Two aspects of the evidence suggest that monopsony cannot be the whole story. The first is that a monopsony achieves its gains by restricting output, and hence takeovers that are motivated only by monopsony should result in lower revenues (though higher profits). Secondly, the monopsony model predicts that an increase in firm share results in lower, not higher hours.

One cannot exclude the possibility that takeovers both increase monopsony power, and also increase the target hospital's revenue per unit of output by shifting $\alpha$. The results for Sutter suggest that such increases in revenue are important since it is otherwise difficult to explain the increases in hours and revenue which accompany takeovers by this chain. However, the fact that effort does not increase at Sutter is inconsistent with the monopsony model, which predicts increases in effort with or without shifts in the hospital's revenue function.

We have not dwelt on the lengthy literature on the potential differences between nonprofit and for-profit firms. Following Arrow (1963), theoretical models of the non-profit firm have often assumed that providers choose the non-profit form in order to signal their high commitment to quality care (c.f. Frank and Salkever (1994); Glaeser and Schleifer (1998)). However, the empirical literature has been hard pressed to demonstrate consistent differences in quality between non-profit and for-profit firms (Sloan (2000); Sloan (2002); and Baker et al. (2000) provide extensive summaries of this literature). For example, Sloan (2002) concludes that conversions in status have little effect on in-hospital mortality or charity care, although pneumonia patients in hospitals that converted to FP status experienced an increased rate of complications. Farsi (2002) uses models which account for heterogeneity between hospitals and finds that conversions to FP are associated with reductions in in-patient and subsequent mortality. However, conversion also increases rates of complications among heart-attack patients, and reduces the probability of being admitted from the emergency room. Thus, it is difficult to conclude that overall quality is higher or lower.

Our work adds to this literature by demonstrating that the two largest California hospital chains have much in common with each other, despite the fact that one is for-profit and the other is non-profit. Moreover, CHW and Tenet are arguably more similar to each other than CHW is to Sutter (the other large non-profit chain), or Tenet is to Columbia-HCA (the other 
large for-profit chain). Thus our work supports the idea that "ownership differences turn out to be much less important than they might seem ... nominal ownership structure seems to matter much less than fundamental economic incentives" (Pauly, 1987 page 262).

Although labor economists have found little evidence of monopsony in the market for nurses, nurses have strongly opposed takeovers of hospitals by large multi-hospital chains. Nurses consistently cite concerns over staffing as one of the key reasons that they dislike the chains. For example, in a discussion of the recent takeover of Queen of Angels-Hollywood Presbyterian Medical Center by Tenet, the California Nurses' Association web site describes concerns that "the hospital's quality of care will decline under Tenet, especially if there are any cuts in the nurse-to-bed ratio" (www.calnurse.org/cal/oct/columbia.htm). By extending the standard monopsony and contract models to incorporate worker effort, the models presented in this paper provide a possible solution to this puzzle. We find that although there is little decline in wages, nurses are consistently asked to work harder after hospitals join chains.

If reductions in nurse-patient ratios do lead to lower quality care, then our results may have broader implications for hospital markets. To the extent that patients can observe quality and choose from hospitals offering a range of quality levels, reductions in quality will be reflected in the price of hospital services. However, in an increasingly concentrated market fraught with asymmetric information problems, there can be no presumption that such reductions in quality are efficient.

\section{References}

[1] Abowd, John and Orley Ashenfelter. "Anticipated Unemployment, Temporary Layoffs, and Compensating Wage Differentials", in Studies in Labor Markets, Sherwin Rosen (ed) (Chicago: University of Chicago Press for NBER), 1981, 141-170.

[2] Altonji, Joseph and Paul Devereux. "The Extent and Consequences of Nominal Wage Rigidity" in Research in Labor Economics, Solomon Polachek (ed), v19, 2000.

[3] Arrow, Kenneth. "Uncertainty and the Welfare Economics of Medical Care", American Economic Review, 53 \#5, 1963, 941-973.

[4] Ashenfelter, Orley. "Estimating the Effect of Training Programs on Earnings", Review of Economics and Statistics, v60 \#1, Feb. 1978, 47-57. 
[5] Ashenfelter, Orley and James Brown. "Testing the Efficiency of Employment Contracts", Journal of Political Economy, V94 \#3, Part 2, June 1986, S40-S87.

[6] Ashenfelter, Orley and Timothy Hannan. "Sex Discrimination and Product Market Competition: The Case of the Banking Industry", Quarterly Journal of Economics, 101 \#1, Feb. 1986, 149-174.

[7] Baker, Constance, P.L. Messmer, and C.C. Gyurko et al. "Hospital Ownership, Performance, and Outcomes: Assessing the State of the Science", Journal of Nursing Administration, v30 \#5, 2000, 227-240.

[8] Barro, Jason. "Efficiency and Monopoly as Explanations for Hospital Mergers", forthcoming in RAND Journal of Economics.

[9] Barro, Jason and David Cutler. "Consolidation in the Medical Care Marketplace: A Case Study of Massachusetts", NBER Working Paper \#5957, Cambridge MA, March 1997.

[10] Boal, William and Michael Ransom. "Monopsony in the Labor Market", Journal of Economic Literature, v35 \#1, March 1997, 86-112.

[11] Buerhaus, Peter and Douglas Staiger. "Trouble in the Nurse Labor Market? Recent Trends and Future Outlook", Health Affairs, v18 \#1, Jan/Feb. 1999, 214-222.

[12] California Office of Statewide Health Planning and Development. Hospital Annual Disclosure Report, (Sacramento: California Office of Statewide Health Planning and Development) 1989-1999.

[13] Clark, Paul, Darlene Clark, David Day, and Dennis Shea. "HealthCare Reform and the Workplace Experience of Nurses: Implications for Patient Care and Union Organizing", Industrial and Labor Relations Review, v55 \#1, October 2001, 133-148.

[14] Conner, Robert, Roger Feldman, and Bryan Dowd. "The Effect of Market Concentration and Horizontal Mergers on Hospital Costs and Prices", International Journal of the Economics of Business, v5 \#2, 1998, 159-180.

[15] Corey-Lisle, Patricia, Anita Tarzian, Marlene Cohen, and Alison Trinkoff. "Healthcare Reform: Its Effect on Nurses", Journal of Nursing Administration, 29 \#3, 30-37.

[16] Currie, Janet and John Fahr. "Hospitals, Managed Care and the Charity Caseload in California", forthcoming in Journal of Health Economics, 2002a. 
[17] Currie, Janet and John Fahr. "Medicaid Managed Care: Effects on Children's Medicaid Coverage and Utilization of Care", August, 1999, revised July 2002 b.

[18] Cutler, David and Jill Horowitz. "Converting Hospitals from Not-For-Profit to For-Profit Status: Why and What Effects?", in David Cutler (ed). The Changing Hospital Industry: Comparing Not-for-Profit and For-Profit Institutions (Cambridge MA: University of Chicago Press for NBER) 2000.

[19] Davidson, Harriet, Patricia Folcarelli, Sybil Crawford, Laura Duprat and Joyce Clifford. "The Effects of Healthcare Reforms on Job Satisfaction and Voluntary Turnover among Hospital Based Nurses", Medical Care, v35 \#4, 883-97.

[20] Dranove, David. "Economies of Scale in Non-Revenue Producing Cost Centers: Implications for Hospital Mergers", Journal of Health Economics, v17, 1998, 69-83.

[21] Dranove, David. The Economic Evolution of American Health Care (Princeton NJ: Princeton University Press) 2000.

[22] Dranove, David and Mark Satterthwaite. "The Industrial Organization of Health Care Markets" in A.J. Culyer and J.P. Newhouse (eds.) Handbook of Health Economics, v1 (Amsterdam: Elsevier Science) 2000, 1093-1139.

[23] Farsi, Mehdi. Essays on Organizational Forms and Performance in California Hospitals, Ph. D Dissertation, University of Southern California, December 2002.

[24] Frank, Richard and David Salkever. "Nonprofit Organizations in the Health Sector", Journal of Economic Perspectives, 8 \#4, 1991, 667-674.

[25] Gaynor, Martin and William Vogt. "Antitrust and Competition in Health Care Markets" in A.J. Culyer and J.P. Newhouse (eds.) Handbook of Health Economics, v1 (Amsterdam: Elsevier Science) 2000, 1405-1487.

[26] Glaeser, Edward and Andrei Shleifer. "Not-for-profit Entrepreneurs" (Cambridge MA: National Bureau of Economic Research) Working Paper \#6810, 1998.

[27] Grout, Paul. "Investment and Wages in the Absence of Binding Contracts: A Nash Bargaining Approach." Econometrica, March, 1984, 52(2), pp. 449-60.

[28] Hall, Carl. "Catholic Healthcare's Kingdom" San Francisco Chronicle, July 26, 1996, B1.

[29] Hart, Oliver D. and Moore, John. "Incomplete Contracts and Renegotiation,." Econometrica, July, 1988, 56(4), pp. 755-85. 
[30] Hirsch, Barry and Edward Schumacher. "Monopsony Power and Relative Wages in the Labor Market for Nurses", Journal of Health Economics, 14 \#4, October 1995, 443-476.

[31] Ho, Vivian and Barton Hamilton. "Hospital Mergers and Acquisitions: Does Market Consolidation Harm Patients?", Journal of Health Economics, v19, 2000, 767-791.

[32] Keeler, E., Glenn Melnick, and J. Zwanziger. "The Changing Effects of Competition on Non-Profit and For-Profit Hospital Pricing Behavior", Journal of Health Economics, v18, 1999, 69-86.

[33] Kessler, Daniel and Mark McClellan. "Is Hospital Competition Socially Wasteful?", Quarterly Journal of Economics, May 2000.

[34] Krishnan, Ranjani. "Market Restructuring and Pricing in the Hospital Industry", Journal of Health Economics, v20, 2001, 213-237.

[35] Madison, Kristin. "Essays on Organizational Forms in the Health Care Industry", Ph.D. Dissertation, Stanford University, 2001.

[36] MacLeod, W. Bentley and James Malcomson. "Investments, Holdup, and the Form of Market Contracts", American Economics Review, v83 \#4, Sept. 1993, 811-837.

[37] _ June, 1998, 388-411.

[38] Mitchell, Shannon, Joanne Spetz, Jean Ann Seago. "Errors in data on hospital ownership" Inquiry - Blue Cross 83 Blue Shield Association v38, \#4, Winter 2001/2002, 432-439.

[39] Needleman, Jack, Peter Buerhaus, Soeren Mattke, Maureen Stewart and Katya Zelevinsky. "Nurse-Staffing Levels and the Quality of Care in Hospitals", New England Journal of Medicine, v346 \#22, May 30, 2002, 1715-1722.

[40] Nicholas C. Petris Center. California's Closed Hospitals, 1995-2000 (Berkeley: Nicholas C. Petris Center on Health Care Markets and Consumer Welfare, Berkeley School of Public Health), April 2001.

[41] Pauly, Mark. "Nonprofit firms in medical markets", American Economic Review, 77 \#2, May, 1987, 257-262.

[42] Simon, Herbert A. "A Formal Theory of the Employment Relationship." Econometrica, July, 1951, 19, pp. 293-305. 
[43] Simpson, John and Richard Shin. "Do Nonprofit Hospitals Exercise Market Power?", International Journal of the Economics of Business, v5 \#2, 141-157.

[44] Sloan, Frank. "Not-for-Profit Ownership and Hospital Behavior", in A.J. Culyer and J.P. Newhouse (eds.) Handbook of Health Economics, v1 (Amsterdam: Elsevier Science) 2000, 1141-1174.

[45] Sloan, Frank. "Hospital Conversions: Defining the Appropriate Public Oversight Role", in Alan Garber (ed.), Frontiers in Health Policy Research, Volume 5 (Cambridge MA: MIT Press for National Bureau of Economic Research) 2002.

[46] Sochalski, Julie and Linda Aiken. "Accounting for Variation in Hospital Outcomes: A Cross-National Study", Health Affairs, May-June, 1999.

[47] Spetz, Joanne, Jean Ann Seago and Shannon Mitchell. "Changes in Hospital Ownership in California", (Sacramento: Public Policy Insinuate of California) 1999.

[48] Spetz, Joanne, Shannon Mitchell and Jean Ann Seago. "The Growth of Multi hospital Firms in California", Health Affairs, v 19 \#6, 2000, 224-230.

[49] Sullivan, Daniel. "Monopsony Power in the Market for Nurses", Journal of Law and Economics v32 \#2, Part 2, October 1989, S135-S178.

[50] Williamson, Oliver E.; Wachter, Michael L. and Harris, Jeffrey E. "Understanding the Employment Relation: The Analysis of Idiosyncratic Exchange." Bell Journal of Economics, Spring, 1975, 6(1), pp. 250-78.

[51] Yett, Donald E. "The Chronic Shortage of Nurses: A Public Policy Dilemma" in Empirical Studies in Health Economics, Herbert Klarman and Helen Jaszi (eds) (Baltimore: Johns Hopkins Press) 1970, 357-389. 
Table 1: Variable Means for Non-Chain and Chain Hospitals

\begin{tabular}{|c|c|c|c|c|c|c|c|}
\hline & Non-Chain & CHW & Sutter & Columbia & Tenet & OrNda & \# Obs. \\
\hline \# beds & $\begin{array}{c}183 \\
{[2.67]}\end{array}$ & $\begin{array}{c}235 \\
{[8.79]}\end{array}$ & $\begin{array}{c}174 \\
{[14.1]}\end{array}$ & $\begin{array}{c}189 \\
{[16.1]}\end{array}$ & $\begin{array}{c}178 \\
{[5.49]}\end{array}$ & $\begin{array}{c}182 \\
{[13.75]}\end{array}$ & 3978 \\
\hline Patient da & $\begin{array}{c}107 \\
{[1.91]}\end{array}$ & $\begin{array}{c}144 \\
{[5.78]}\end{array}$ & $\begin{array}{c}109 \\
{[10.36]}\end{array}$ & $\begin{array}{c}79 \\
{[6.62]}\end{array}$ & $\begin{array}{c}89 \\
{[3.38]}\end{array}$ & $\begin{array}{c}72 \\
{[6.00]}\end{array}$ & 3978 \\
\hline $\begin{array}{l}\text { Gross Pati } \\
(100,000 \mathrm{~s})\end{array}$ & $\begin{array}{c}353 \\
{[8.14]}\end{array}$ & $\begin{array}{c}546 \\
{[.278]}\end{array}$ & $\begin{array}{c}491 \\
{[.526]}\end{array}$ & $\begin{array}{c}391 \\
{[.353]}\end{array}$ & $\begin{array}{c}471 \\
{[.260]}\end{array}$ & $\begin{array}{c}285 \\
{[.218]}\end{array}$ & 3971 \\
\hline \multicolumn{8}{|l|}{ Wages } \\
\hline$\overline{R N}$ & $\begin{array}{l}19.60 \\
{[.082]}\end{array}$ & $\begin{array}{l}21.80 \\
{[.314]}\end{array}$ & $\begin{array}{l}23.28 \\
{[.513]}\end{array}$ & $\begin{array}{l}23.88 \\
{[.493]}\end{array}$ & $\begin{array}{l}21.44 \\
{[.252]}\end{array}$ & $\begin{array}{l}21.85 \\
{[.295]}\end{array}$ & 3978 \\
\hline LVN & $\begin{array}{l}12.10 \\
{[.066]}\end{array}$ & $\begin{array}{l}13.77 \\
{[.182]}\end{array}$ & $\begin{array}{l}13.86 \\
{[.294]}\end{array}$ & $\begin{array}{l}14.96 \\
{[.272]}\end{array}$ & $\begin{array}{l}13.51 \\
{[.162]}\end{array}$ & $\begin{array}{l}13.82 \\
{[.306]}\end{array}$ & 3914 \\
\hline Aide & $\begin{array}{c}8.30 \\
{[.036]}\end{array}$ & $\begin{array}{c}9.25 \\
{[.135]}\end{array}$ & $\begin{array}{c}9.99 \\
{[.235]}\end{array}$ & $\begin{array}{l}10.44 \\
{[.228]}\end{array}$ & $\begin{array}{c}9.01 \\
{[.126]}\end{array}$ & $\begin{array}{c}8.77 \\
{[.169]}\end{array}$ & 3934 \\
\hline Contract & $\begin{array}{l}32.26 \\
{[.228]}\end{array}$ & $\begin{array}{l}33.02 \\
{[.694]}\end{array}$ & $\begin{array}{l}33.50 \\
{[.751]}\end{array}$ & $\begin{array}{l}31.00 \\
{[.925]}\end{array}$ & $\begin{array}{l}29.53 \\
{[1.30]}\end{array}$ & $\begin{array}{l}30.50 \\
{[1.56]}\end{array}$ & 1594 \\
\hline \multicolumn{8}{|l|}{ Hours } \\
\hline $\mathrm{RN}$ & $\begin{array}{c}878 \\
{[17.2]}\end{array}$ & $\begin{array}{c}1084 \\
{[47.91]}\end{array}$ & $\begin{array}{c}966 \\
{[91.07]}\end{array}$ & $\begin{array}{c}740 \\
{[69.05]}\end{array}$ & $\begin{array}{c}720 \\
{[31.69]}\end{array}$ & $\begin{array}{c}579 \\
{[51.19]}\end{array}$ & 3978 \\
\hline LVN & $\begin{array}{c}129 \\
{[2.28]}\end{array}$ & $\begin{array}{c}178 \\
{[10.6]}\end{array}$ & $\begin{array}{c}147 \\
{[14.5]}\end{array}$ & $\begin{array}{c}95 \\
{[9.19]}\end{array}$ & $\begin{array}{c}92 \\
{[4.42]}\end{array}$ & $\begin{array}{c}87 \\
{[9.01]}\end{array}$ & 3914 \\
\hline Aide & $\begin{array}{c}268 \\
{[17.23]}\end{array}$ & $\begin{array}{c}291 \\
{[15.90]}\end{array}$ & $\begin{array}{c}248 \\
{[29.38]}\end{array}$ & $\begin{array}{c}204 \\
{[23.96]}\end{array}$ & $\begin{array}{c}176 \\
{[8.13]}\end{array}$ & $\begin{array}{c}99 \\
{[8.31]}\end{array}$ & 3934 \\
\hline Contract & $\begin{array}{c}28.8 \\
{[2.98]}\end{array}$ & $\begin{array}{c}33.5 \\
{[3.66]}\end{array}$ & $\begin{array}{c}33.7 \\
{[9.47]}\end{array}$ & $\begin{array}{c}39.9 \\
{[7.09]}\end{array}$ & $\begin{array}{c}24.3 \\
{[3.15]}\end{array}$ & $\begin{array}{c}29.3 \\
{[6.33]}\end{array}$ & 2505 \\
\hline \multicolumn{8}{|l|}{ Effort } \\
\hline$\overline{\mathrm{RN}}$ & $\begin{array}{c}4.36 \\
{[.134]}\end{array}$ & $\begin{array}{c}3.69 \\
{[.200]}\end{array}$ & $\begin{array}{c}2.73 \\
{[.114]}\end{array}$ & $\begin{array}{c}2.69 \\
{[.068]}\end{array}$ & $\begin{array}{c}3.37 \\
{[.117]}\end{array}$ & $\begin{array}{c}3.10 \\
{[.118]}\end{array}$ & 3978 \\
\hline $\mathrm{RN}+\mathrm{LVN}$ & $\begin{array}{c}2.23 \\
{[.023]}\end{array}$ & $\begin{array}{c}2.31 \\
{[.051]}\end{array}$ & $\begin{array}{c}1.89 \\
{[.051]}\end{array}$ & $\begin{array}{c}1.88 \\
{[.048]}\end{array}$ & $\begin{array}{c}2.28 \\
{[.043]}\end{array}$ & $\begin{array}{c}2.26 \\
{[.055]}\end{array}$ & 3978 \\
\hline $\mathrm{RN}+\mathrm{LVN}$ & $\begin{array}{c}2.08 \\
{[.022]}\end{array}$ & $\begin{array}{c}2.22 \\
{[.059]}\end{array}$ & $\begin{array}{c}1.81 \\
{[.053]}\end{array}$ & $\begin{array}{c}1.81 \\
{[.047]}\end{array}$ & $\begin{array}{c}2.15 \\
{[.040]}\end{array}$ & $\begin{array}{c}2.20 \\
{[.053]}\end{array}$ & 2505 \\
\hline Firm Share & $\begin{array}{l}0.034 \\
{[.001]}\end{array}$ & $\begin{array}{l}0.090 \\
{[.005]}\end{array}$ & $\begin{array}{l}0.099 \\
{[.009]}\end{array}$ & $\begin{array}{l}0.044 \\
{[.006]}\end{array}$ & $\begin{array}{l}0.075 \\
{[.003]}\end{array}$ & $\begin{array}{l}0.029 \\
{[.002]}\end{array}$ & 3978 \\
\hline H S A Her & $\begin{array}{l}0.083 \\
{[.001]}\end{array}$ & $\begin{array}{l}0.122 \\
{[.004]}\end{array}$ & $\begin{array}{l}0.133 \\
{[.004]}\end{array}$ & $\begin{array}{l}0.104 \\
{[.007]}\end{array}$ & $\begin{array}{l}0.074 \\
{[.002]}\end{array}$ & $\begin{array}{l}0.061 \\
{[.005]}\end{array}$ & 3978 \\
\hline \# Observa & 3298 & 187 & 117 & 63 & 254 & 59 & \\
\hline
\end{tabular}

Note: Standard errors in brackets. 
Table 2: Effects of Hospital Takeovers by Large Chains

\begin{tabular}{|c|c|c|c|c|c|c|c|c|c|}
\hline \multirow{7}{*}{ 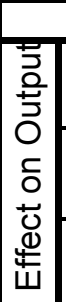 } & \multirow{3}{*}{ Number of beds } & $\mathrm{CHW}$ & Sutter & Columbia & Tenet & OrNda & \#obs. & \#hospitals & R-sg \\
\hline & & -0.013 & 0.032 & -0.059 & 0.030 & 0.035 & 3978 & 446 & 0.067 \\
\hline & & $(0.019)$ & $(0.028)$ & $(0.026)$ & $(0.021)$ & $(0.026)$ & & & \\
\hline & \multirow{2}{*}{ patient days } & 0.056 & 0.093 & -0.007 & 0.012 & 0.126 & 3977 & 446 & 0.062 \\
\hline & & $(0.034)$ & $(0.052)$ & (90.048) & $(0.038)$ & $(0.047)$ & & & \\
\hline & \multirow{2}{*}{ gross patient revenues } & 0.056 & 0.141 & -0.045 & 0.093 & 0.157 & 3970 & 446 & 0.644 \\
\hline & & $(0.027)$ & $(0.040)$ & $(0.037)$ & $(0.030)$ & $(0.037)$ & & & \\
\hline \multirow{8}{*}{ 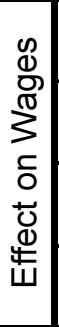 } & \multirow{2}{*}{ RN } & -0.029 & 0.015 & -0.010 & 0.000 & 0.024 & 3978 & 446 & 0.586 \\
\hline & & $(0.011)$ & $(0.017)$ & $(0.016)$ & $(0.012)$ & $(0.016)$ & & & \\
\hline & \multirow{2}{*}{ LVN } & -0.008 & 0.040 & -0.040 & 0.003 & 0.034 & 3914 & 440 & 0.445 \\
\hline & & $(0.014)$ & $(0.021)$ & $(0.019)$ & $(0.015)$ & $(0.019)$ & & & \\
\hline & \multirow{2}{*}{ Aides } & -0.025 & -0.007 & -0.035 & -0.007 & 0.003 & 3934 & 443 & 0.399 \\
\hline & & $(0.012)$ & $(0.018)$ & $(0.017)$ & $(0.013)$ & $(0.017)$ & & & \\
\hline & \multirow{2}{*}{ Contract Workers } & 0.032 & 0.117 & 0.017 & -0.149 & 0.174 & 1593 & 354 & 0.119 \\
\hline & & 0.046 & 0.070 & 0.065 & 0.050 & 0.065 & & & \\
\hline \multirow{6}{*}{ 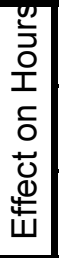 } & \multirow{2}{*}{ RN } & -0.046 & 0.112 & -0.056 & -0.079 & 0.084 & 3978 & 446 & 0.105 \\
\hline & & $(0.028)$ & $(0.042)$ & $(0.039)$ & $(0.031)$ & $(0.038)$ & & & \\
\hline & \multirow{2}{*}{ Total RN+LVN+Aides } & -0.039 & 0.088 & -0.011 & -0.114 & 0.044 & 3978 & 446 & 0.1067 \\
\hline & & $(0.026)$ & $(0.038)$ & $(0.036)$ & $(0.028)$ & $(0.035)$ & & & \\
\hline & \multirow{2}{*}{ Total Nursing Staff } & -0.032 & 0.092 & -0.051 & -0.151 & -0.038 & 2506 & 424 & 0.0965 \\
\hline & & $(0.029)$ & $(0.042)$ & $(0.043)$ & $(0.034)$ & $(0.044)$ & & & \\
\hline \multirow{6}{*}{ 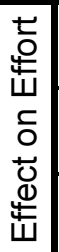 } & \multirow{2}{*}{ RN } & 0.101 & -0.021 & 0.048 & 0.091 & 0.042 & 3977 & 446 & 0.0988 \\
\hline & & $(0.036)$ & $(0.054)$ & $(0.050)$ & $(0.039)$ & $(0.049)$ & & & \\
\hline & \multirow{2}{*}{ Total RN+LVN+Aides } & 0.093 & 0.003 & 0.003 & 0.126 & 0.081 & 3977 & 446 & 0.1304 \\
\hline & & $(0.029)$ & $(0.043)$ & $(0.040)$ & $(0.032)$ & $(0.040)$ & & & \\
\hline & \multirow{2}{*}{ Total Nursing Staff } & 0.079 & 0.005 & 0.076 & 0.083 & 0.067 & 2505 & 424 & 0.0943 \\
\hline & & $(0.032)$ & $(0.047)$ & $(0.048)$ & $(0.038)$ & $(0.050)$ & & & \\
\hline
\end{tabular}

Notes: Each row represents output from a separate regression. All regressions include H $M$ S A*year and hospital year effects. Bold face indicates significance at the $95 \%$ level of confidence. 
Table 3: Effects of Takeovers by Large Hospital Chains and Firm Share

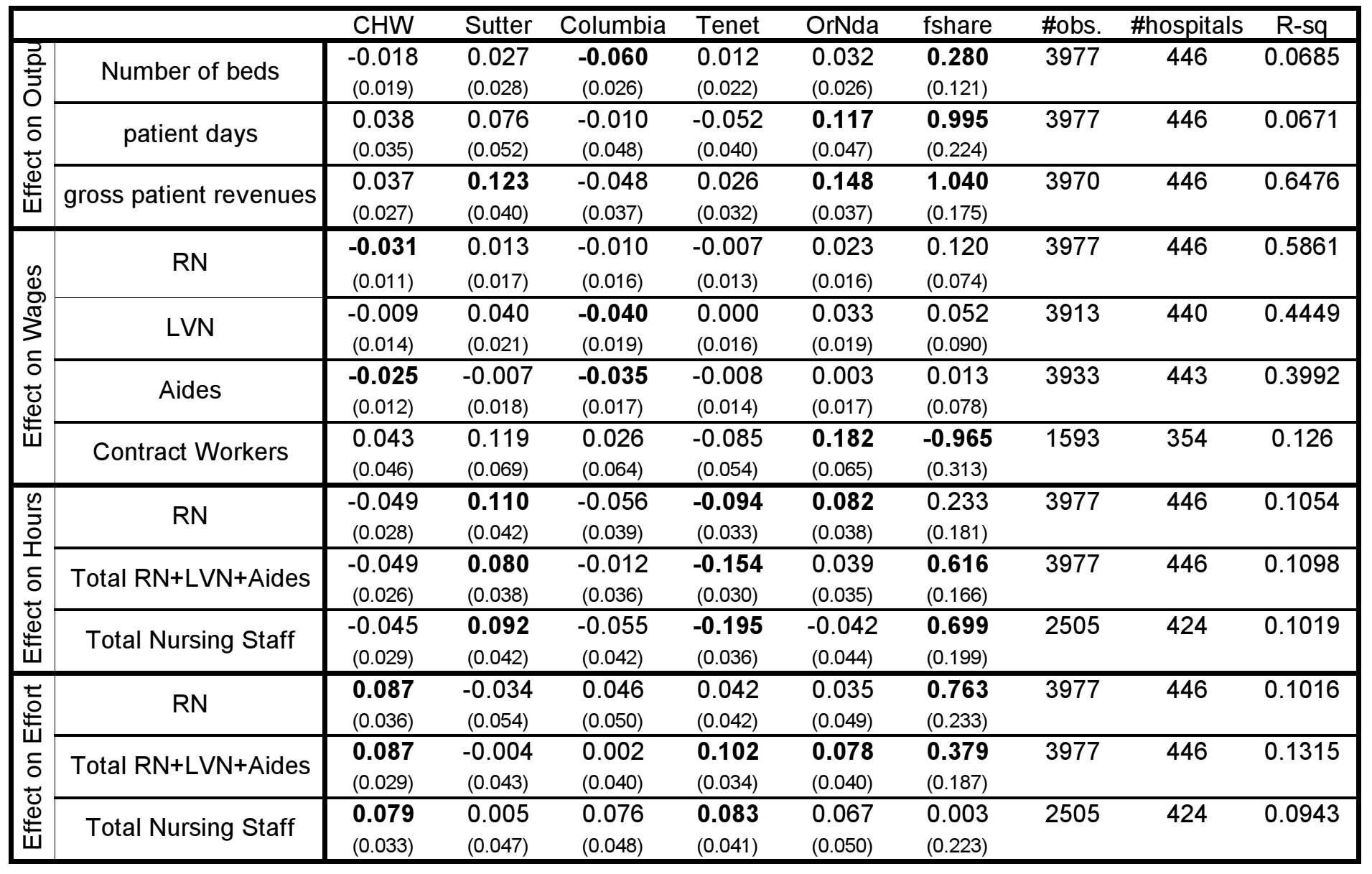

Notes: Each row represents output from a separate regression. All regressions include H: *year and hospital year effects. Bold face indicates significance at the $95 \%$ level of confidence. 
Table 4: Variation in Effects of Mergers with Firm Size

\begin{tabular}{|c|c|c|c|c|c|c|c|}
\hline & & & Chain* & No Chain* & & & \\
\hline & & Chain & Firm Size & Firm Size & \#obs. & \#hospitals & R-sq \\
\hline \multirow{3}{*}{ 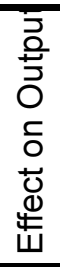 } & $\begin{array}{l}\text { Number } \\
\text { of beds }\end{array}$ & $\begin{array}{c}-0.004 \\
(0.015)\end{array}$ & $\begin{array}{l}\mathbf{0 . 2 9 3} \\
(0.140)\end{array}$ & $\begin{array}{l}0.331 \\
(0.169)\end{array}$ & 3978 & 446 & 0.066 \\
\hline & $\begin{array}{c}\text { patient } \\
\text { days }\end{array}$ & $\begin{array}{l}\mathbf{0 . 0 8 4} \\
(0.027)\end{array}$ & $\begin{array}{l}0.362 \\
(0.257)\end{array}$ & $\begin{array}{l}\mathbf{1 . 5 7 0} \\
(0.311)\end{array}$ & 3977 & 446 & 0.067 \\
\hline & $\begin{array}{l}\text { gross } \\
\text { patient }\end{array}$ & $\begin{array}{l}\mathbf{0 . 0 6 4} \\
(0.021)\end{array}$ & $\begin{array}{l}\mathbf{0 . 8 5 3} \\
(0.201)\end{array}$ & $\begin{array}{l}1.190 \\
(0.244)\end{array}$ & 3970 & 446 & 0.646 \\
\hline \multirow{4}{*}{ 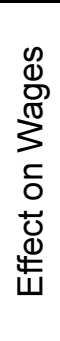 } & RN & $\begin{array}{l}0.008 \\
(0.009)\end{array}$ & $\begin{array}{l}-0.030 \\
(0.084)\end{array}$ & $\begin{array}{l}\mathbf{0 . 3 2 6} \\
(0.102)\end{array}$ & 3978 & 446 & 0.586 \\
\hline & LVN & $\begin{array}{l}0.007 \\
(0.011)\end{array}$ & $\begin{array}{c}-0.008 \\
(0.103)\end{array}$ & $\begin{array}{l}0.133 \\
(0.125)\end{array}$ & 3914 & 440 & 0.443 \\
\hline & Aides & $\begin{array}{c}-\mathbf{0 . 0 2 1} \\
(0.010)\end{array}$ & $\begin{array}{l}0.060 \\
(0.090)\end{array}$ & $\begin{array}{c}-0.036 \\
(0.109)\end{array}$ & 3934 & 443 & 0.399 \\
\hline & $\begin{array}{l}\text { Contract } \\
\text { Workers }\end{array}$ & $\begin{array}{l}0.077 \\
(0.037)\end{array}$ & $\begin{array}{r}-1.690 \\
(0.319) \\
\end{array}$ & $\begin{array}{c}-0.999 \\
(0.463)\end{array}$ & 1593 & 354 & 0.109 \\
\hline \multirow{3}{*}{ 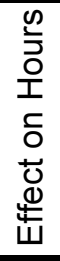 } & RN & $\begin{array}{l}0.009 \\
(0.022) \\
\end{array}$ & $\begin{array}{c}-0.153 \\
(0.208) \\
\end{array}$ & $\begin{array}{l}0.418 \\
(0.253) \\
\end{array}$ & 3978 & 446 & 0.099 \\
\hline & $\begin{array}{c}\text { Total } \\
\text { RN+LVN+ }\end{array}$ & $\begin{array}{l}0.004 \\
(0.020)\end{array}$ & $\begin{array}{l}0.074 \\
(0.192)\end{array}$ & $\begin{array}{l}\mathbf{0 . 8 4 5} \\
(0.234)\end{array}$ & 3978 & 446 & 0.103 \\
\hline & $\begin{array}{c}\text { Total } \\
\text { Nursing }\end{array}$ & $\begin{array}{c}-0.024 \\
(0.024)\end{array}$ & $\begin{array}{l}0.194 \\
(0.207) \\
\end{array}$ & $\begin{array}{l}\mathbf{0 . 7 1 5} \\
(0.298) \\
\end{array}$ & 2506 & 424 & 0.087 \\
\hline \multirow{3}{*}{ 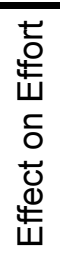 } & RN & $\begin{array}{l}\mathbf{0 . 0 7 5} \\
(0.028)\end{array}$ & $\begin{array}{l}0.515 \\
(0.267)\end{array}$ & $\begin{array}{l}\mathbf{1 . 1 5 0} \\
(0.324)\end{array}$ & 3977 & 446 & 0.101 \\
\hline & $\begin{array}{c}\text { Total } \\
\text { RN+LVN+ }\end{array}$ & $\begin{array}{l}0.080 \\
(0.023) \\
\end{array}$ & $\begin{array}{l}0.289 \\
(0.215) \\
\end{array}$ & $\begin{array}{l}\mathbf{0 . 7 2 2} \\
(0.026) \\
\end{array}$ & 3977 & 446 & 0.13 \\
\hline & $\begin{array}{c}\text { Total } \\
\text { Nursing }\end{array}$ & $\begin{array}{l}\mathbf{0 . 0 6 6} \\
(0.027)\end{array}$ & $\begin{array}{l}0.050 \\
(0.231)\end{array}$ & $\begin{array}{l}0.077 \\
(0.333)\end{array}$ & 2505 & 424 & 0.093 \\
\hline
\end{tabular}

Notes: Each row represents output from a separate regression. AlH S A*year

and hospital year effects. Bold face indicates significance at the $95 \%$ level of confidence. 

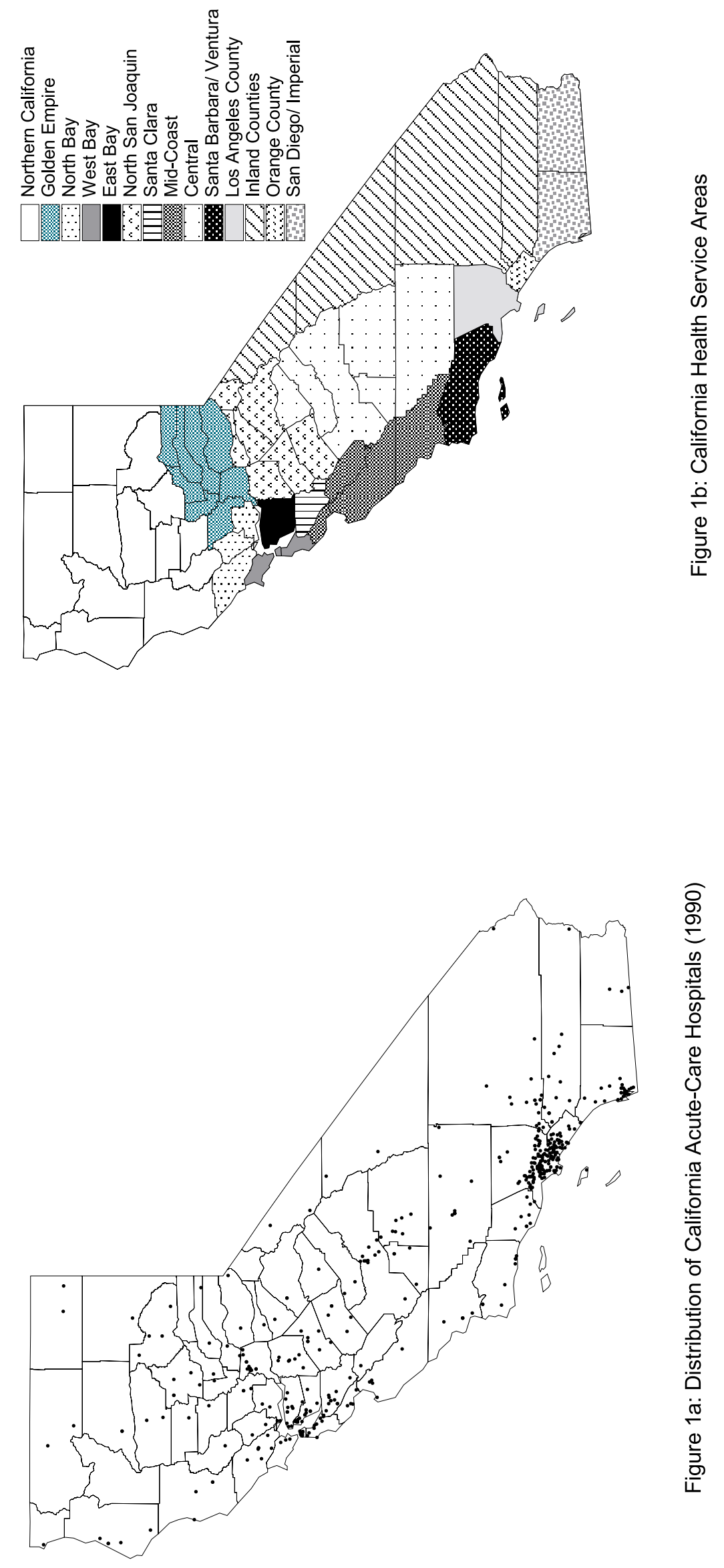

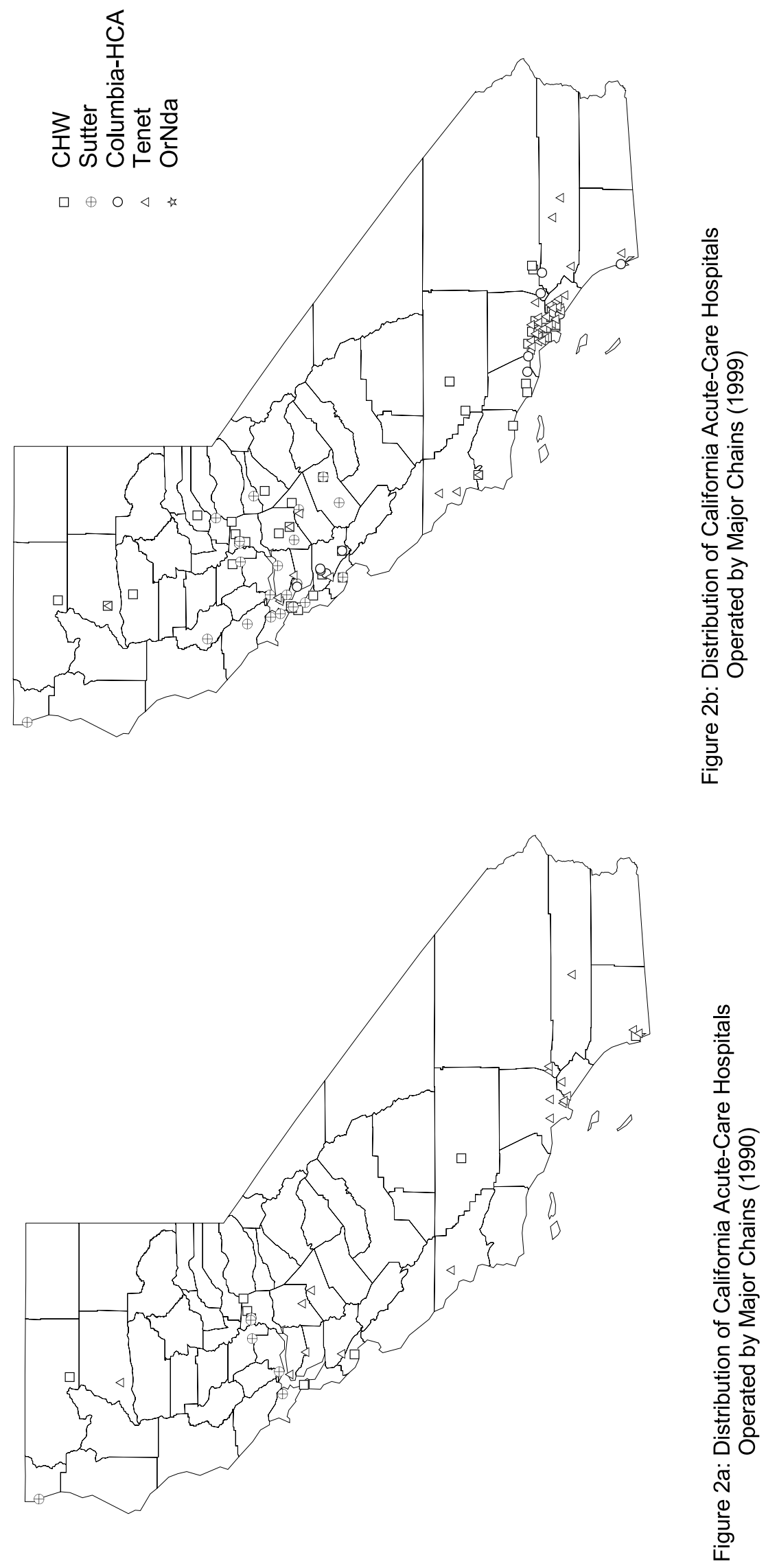

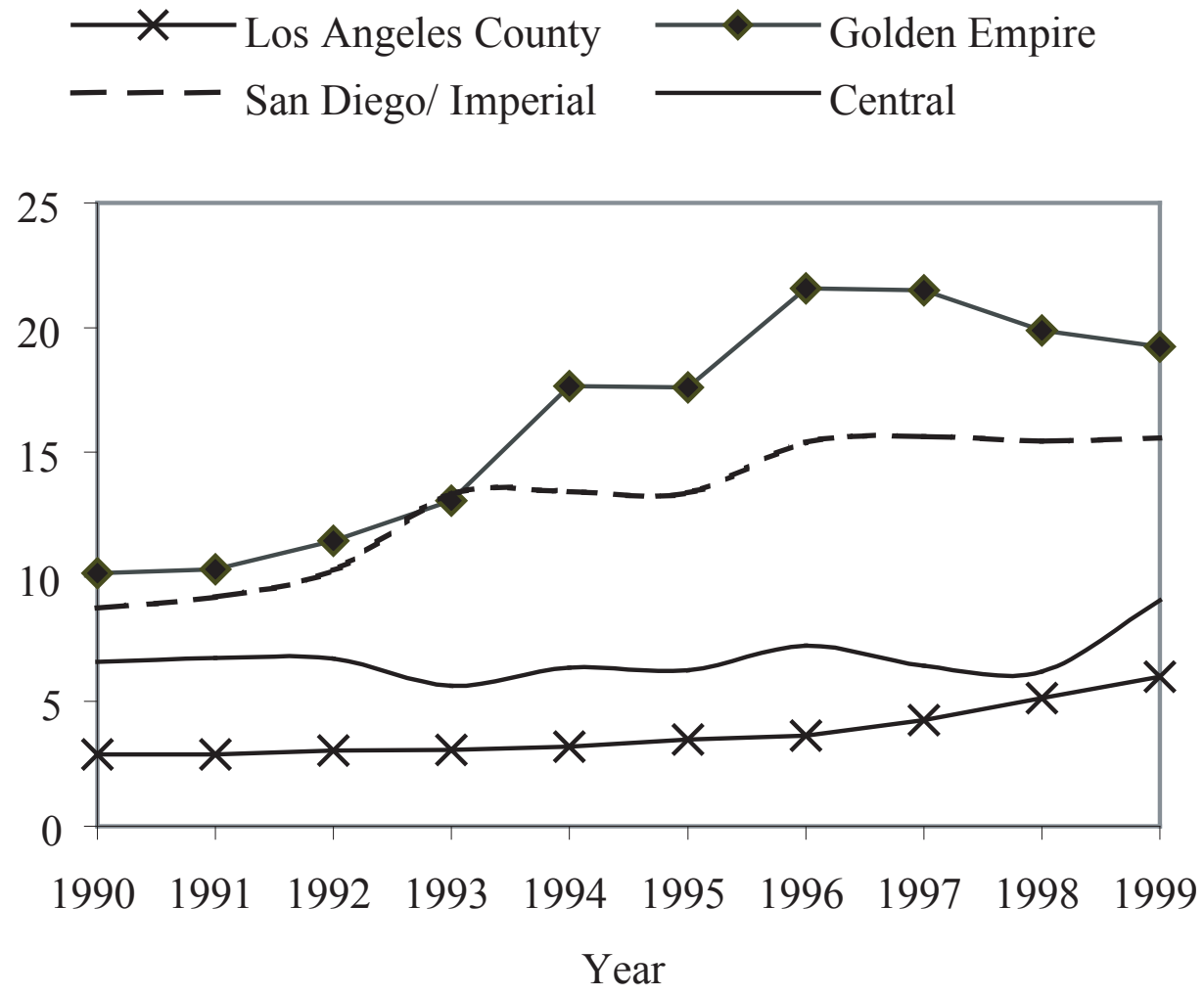

Figure 3 - Herfindahl Index (\%) of Selected Health Service Areas in California 


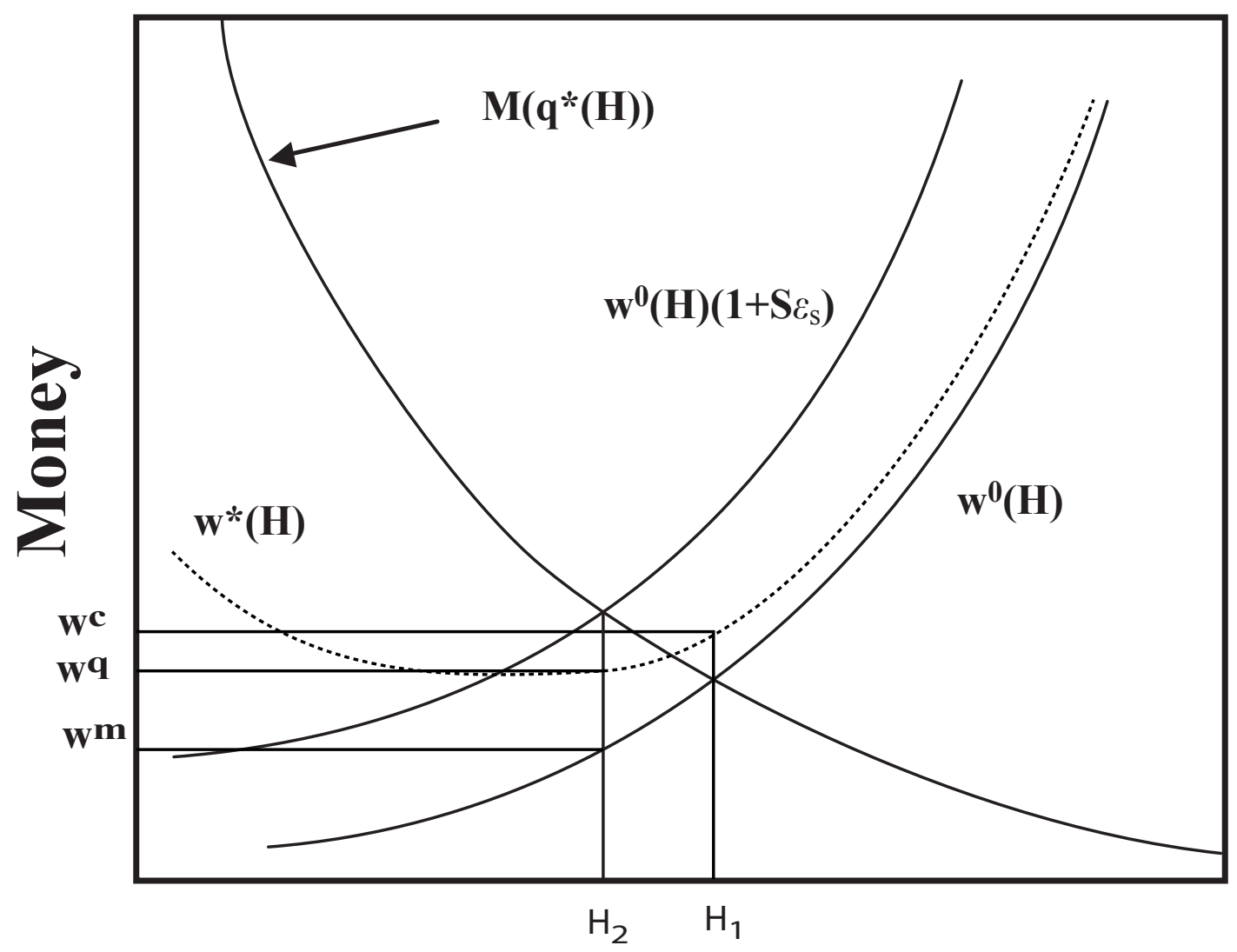

Hours

Figure 4: Equilibrium in an Monopolistic Market with Endogenous Effort 